\title{
PENGARUH KUALITAS PRODUK, KUALITAS LAYANAN, DAN CITRA MEREK TERHADAP LOYALITAS NASABAH YANG DIMEDIASI OLEH KEPUASAN NASABAH (Studi pada Nasabah PT. BRI (Persero) Tbk. Yogyakarta)
}

\author{
Lita Ningrum Afriani \\ lita1400011247@webmail.uad.ac.id \\ Universitas Ahmad Dahlan \\ Hendro Setyono \\ Hendro.setyono@yahoo.com \\ Universitas Ahmad Dahlan
}

\begin{abstract}
ABSTRAK
For companies, loyal customers mean a lot besides illustrates the amount of profitability obtained by loyal consumers can also show the image or image of the company in the public eye. Loyal customers can become partners in developing new products, because they maintain and defend and even use the services of existing companies. According to Darsono (2004) a loyal customer becomes a valuable asset for the company. Loyal customers will reduce the effort to find new customers, giving positive feedback to the company. Companies must be able to satisfy old customers and create new customers, if you want to win the competition. PT. BRI (Persero) Tbk. Yogyakarta must be able to answer the existing competition challenges. The population in this study are customers of Bank Rakyat Indonesia Yogyakarta and have been customers for at least one year. While the sample in this study is a portion of the number of customers from BRI Bank Yogyakarta. The sampling technique uses accidental sampling and purposive sampling. While the data used in the study are primary data, that is data obtained directly from respondents by the researchers themselves through questionnaires. Analysis tools using multiple linear regression The results of the analysis can be concluded that: Product quality has a significant effect on customer satisfaction. Service quality has a significant effect on customer satisfaction. Brand image does not significantly influence customer satisfaction. Product quality, service quality and brand image together significantly influence customer satisfaction. Product quality does not significantly influence customer loyalty. Service quality has a significant effect on customer loyalty. Brand image does not significantly influence customer loyalty. Product quality, service quality and brand image together significantly influence customer loyalty. Customer satisfaction significantly influences customer loyalty. Customer satisfaction mediates the effect of product quality on customer loyalty. Customer satisfaction does not mediate the effect of service quality on customer loyalty. Customer satisfaction does not mediate the effect of brand image on loyalty the customer.
\end{abstract}

Keyword: Product Quality; Service Quality; Brand Image; Satisfaction Customer; Customer Loyalty. 


\section{PENDAHULUAN}

Dunia perbankan di Indonesia telah terjadi perubahan yang cukup menarik yaitu bergesernya bisnis perbankan, dari perbankan yang melayani perusahaan (corporate banking) menjadi lebih fokus pada melayani perseorangan (consumer banking). Pergeseran ini terjadi setelah krisis ekonomi melanda pada tahun 1997, ketika banyak pelaku bisnis mengalami masalah serius kondisi keuangan usaha yang dijalankan. Perbankan yang fokus pada consumer banking lebih mampu bertahan daripada perbankan yang fokus pada corporate banking. Semakin banyak bank yang beralih menggarap pasar konsumen membuat persaingan antar bank semakin tinggi. Persaingan yang ketat ini mendorong perbankan untuk menciptakan keuntungan yang kompetitif (Suhardi, 2003).

Masyarakat sebagai konsumen tentu selalu mengharapkan adanya pelayanan yang baik dalam usaha memenuhi kebutuhan dan keinginannya, hal ini disebabkan karena berkembangnya ekonomi, teknologi dan daya pikir, membuat konsumen menyadari bahwa mereka mempunyai hak untuk mendapatkan pelayanan yang baik serta biaya yang dikeluarkan untuk memenuhi kebutuhan dan keinginan harus sesuai dengan yang diterima, sehingga dalam rangka pemenuhan kebutuhan dan keinginan tersebut harus diiringi oleh diperolehnya kepuasan.

Dalam menciptakan kepuasan konsumen, perusahaan harus dapat meningkatkan nilai maupun citra dari merek yang dimilikinya. Semakin baik penilaian konsumen, akan semakin tinggi pula kepuasannya. Kepuasan konsumen merupakan faktor utama dalam menilai kualitas pelayanan, dimana konsumen menilai kinerja pelayanan yang diterima dan yang dirasakan langsung terhadap suatu produk. Kualitas pelayanan ditentukan oleh bagaimana tingkat kesesuaian antara pelayanan yang diberikan dengan harapan yang diharapkan oleh pengguna layanan. Semakin tinggi kualitas pelayanan yang dirasakan akan semakin tinggi tingkat kepuasan pengguna/pelanggan, selanjutnya akan berdampak positif pada perilaku ataupun niat seseorang dalam menyikapi pelayanan tersebut.Menurut Peter dan Jerry (2014: 24) Penting untuk diakui bahwa memengaruhi perilaku konsumen terbuka itu sangat penting. Apabila konsumen hanya berubah pikiran dan perasaan, namun tidak berbut apapun maka tidak akan terjadi perubahan, tidak ada penjualan, dan tidak ada laba yang dapat diraih. Jadi, mengubah afeksi dan kognisi konsumen seringkali sangat berguna dan penting dalam memngaruhi peilaku konsumen terbuka, tetapi acap kali hanya menjadi tahapan antara dalam proses pengaruh. Konsumen harus melakukan satu perilaku terbuka atau lebih, seperti interaksi dengan toko, interaksi dengan produk, transaksi, konsumsi, atau komunikasi, barulah strategi pemasaran dapat menguntungkan perusahaan. Produk dan merek pun tidak dapat memenuhi kebutuhan dan keinginan konsumenn kecuali jika terjadi perilaku tertentu seperti membeli dan menggunakan produk dan merek tersebut. Disamping itu, loyalitas konsumen juga tidak kalah relevannya untuk dianalisis sebab sikap loyal konsumen akan timbul setelah konsumen mendapatkan kepuasan. Alasan merasakan puas atau tidak puas terhadap layanan yang diterimanya.. Hal inilah yang menjadi latar belakang pemikiran mengapa tema ini menarik untuk diteliti. Penelitian ini dilakukan di Bank BRI Yogyakarta. Dipilihnya Bank BRI sebagai objek penelitian, oleh karena PT. Bank Rakyat Indonesia (Persero), Tbk. atau Bank BRI adalah salah satu bank pemerintah terbesar di Indonesia. Sejak tahun 2005, Bank BRI terus tercatat sebagai bank pencetak laba terbesar di Indonesia. Menutup tahun 2014, Bank BRI mencatat perolehan laba bersih sebesar Rp. 24,20 Triliun atau 
meningkat sebesar $14,35 \%$ dari tahun sebelumnya. Dengan demikian, pada tahun 2014, Bank BRI kembali berhasil dinobatkan sebagai Bank penghasil laba terbesar di Indonesia, mengalahkan seluruh bank umum lainnya.

Berdasarkan informasi yang didapat dari Situs Resmi Bank BRI, yaitu bri.co.id, peningkatan laba bersih tersebut mayoritas ditopang oleh kontribusi dari penyaluran kredit yang meningkat, khususnya kredit untuk Usaha Mikro, Kecil dan Menengah (UMKM). Penyaluran kredit Bank BRI menguasai industri perbankan nasional, dengan total outstanding atau baki debet kredit Bank BRI tahun 2014 meningkat sebesar Rp. 57,79 Triliun atau tumbuh sebesar $13,88 \%$. Dapat disimpulkan bahwa pertumbuhan portofolio kredit berpengaruh signifikan terhadap produktivitas Bank BRI. Untuk mencapai pertumbuhan penyaluran kredit tersebut, Bank BRI Kantor Pusat menyusun Rencana Jangka Panjang (RJP) yang berisi strategi bisnis selama 5 (lima) tahun kedepan, yaitu mulai tahun 2013 sampai dengan tahun 2017. RJP tersebut kemudian diturunkan dalam Rencana Bisnis Bank (RBB), yaitu rencana kegiatan usaha bank jangka pendek dan jangka menengah, termasuk rencana untuk meningkatkan kinerja usaha, serta strategi untuk merealisasikan rencana tersebut sesuai dengan target dan waktu yang telah ditetapkan. Agar lebih terukur dan mudah untuk dicapai, maka RBB diturunkan lagi dalam Rencana Kerja Anggaran Perusahaan (RKAP), yaitu strategi bank dalam jangka waktu 1 (satu) tahun, termasuk target kinerja bank, salah satunya yaitu target delta atau pertumbuhan penyaluran kredit.

Kemudian target tersebut diberikan kepada seluruh unit kerja Bank BRI dengan mempertimbangkan potensi bisnis pada masing-masing unit kerjanya, termasuk Kantor Cabang BRI Jakarta Otista Kemampuan Bank BRI untuk dapat memberikan layanan yang maksimal dari produk-produk yang di beli dan atau digunakan oleh nasabah, serta kemampuan untuk beradaptasi terhadap perubahan dan kemajuan lingkungan, sosial-budaya serta teknologi, dan perilaku nasabahnya menjadi hal yang sangat penting saat ini.

\section{Rumusan Masalah}

1. Apakah terdapat pengaruh positif kualitas produk terhadap kepuasan nasabah di Bank BRI Yogyakarta?

2. Apakah terdapat pengaruh positif kualitas layanan terhadap kepuasan nasabah di Bank BRI Yogyakarta?

3. Apakah terdapat pengaruh citra merek terhadap kepuasan nasabah di Bank BRI Yogyakarta?

4. Apakah terdapat pengaruh kualitas produk, kualitas layanan dan citra merek terhadap kepuasan nasabah di Bank BRI Yogyakarta?

5. Apakah terdapat pengaruh positif kualitas produk terhadap loyalitas nasabah di Bank BRI Yogyakarta?

6. Apakah terdapat pengaruh positif kualitas layanan terhadap loyalitas nasabah di Bank BRI Yogyakarta?

7. Apakah terdapat pengaruh citra merek terhadap loyalitas nasabah di Bank BRI Yogyakarta?

8. Apakah terdapat pengaruh kualitas produk, kualitas layanan dan citra merek terhadap loyalitas nasabah di Bank BRI Yogyakarta?

9. Apakah terdapat pengaruh positif kepuasan nasabah terhadap loyalitas nasabah di Bank BRI Yogyakarta?

\section{REVIEW LITERATUR DAN HIPOTESIS}

\section{Landasan Teori}

\section{Kualitas Produk}

Pengertian kualitas produk menurut Kotler and Armstrong (2012: 283) adalah "the ability of a product to perform its functions, it includes the product's overall durability, reliability, precision, ease of operation and repair, and other valued attributes" dengan arti kemampuan sebuah 
produk dalam memperagakan fungsinya, hal itu termasuk keseluruhan durabilitas, reliabilitas, ketepatan, kemudahan, pengoperasian, dan reparasi produk juga atribut produk lainnya. Sedangkan Feingenbaum dalam Marwanto (2015) mendefinisikan kualitas produk merupakan seluruh gabungan karakteristik produk dari pemasaran, rekayasa (perencanaan), pembuatan (produk) dan pemeliharaan yang membuat produk yang digunakan memenuhi harapan harapan pelanggan.

\section{Kualitas Layanan (Jasa)}

Kualitas sebagaimana diinterpretasikan ISO 9000 merupakan perpaduan antara sifat dan karakteristik yang menentukan sejauh mana keluaran dapat memenuhi persyaratan kebutuhan pelanggan. Pelanggan yang menentukan dan menilai sampai seberapa jauh sifat dan karakteristik itu memenuhi kebutuhannya. Menurut Tjiptono dan Chandra (2012) mendefinisikan kualitas pelayanan adalah ukuran seberapa bagus tingkat layanan yang diberikan mampu sesuai dengan ekspektasi pelanggan. Definisi lain kualitas pelayanan menurut Wyckof dalam Lovelock yang dikutip oleh Tjiptono dan Chandra (2012) merupakan tingkat keunggulan (excellence) yang diharapkan dan pengendalian atas keunggulan tersebut untuk memenuhi keinginan pelanggan.

\section{Citra Merek}

Brand image (citra merek) dapat dianggap sebagai jenis asosiasi yang muncul dibenak konsumen ketika mengingat sebuah merek tertentu. Asosiasi tersebut secara sederhana dapat muncul dalam bentuk pemikiran atau citra tertentu yang dikaitkan dengan suatu merek, sama halnya ketika kita berpikir mengenai orang lain. Menurut Tjiptono dan Chandra (2016:205) Merek sering ddinterpretasikan secara berbeda-beda, di antaranya sebagai tanda kepemiliman, alat diferensiasi, alat fungsional, alat simbolis, risk reducer, shorthand device, legal device, dan strategic device. Walaupun demikian, definisi merek yang paling banyak diacu adala versi American Marketing Association (AMA) yang merumuskan merek sebagai "nama, istilah, tanda, sim dan jasa dari satu penjual atau sekelompok penjual dan membedakan dari barang dan jasa para pesaingnya. Merek bermanfaat bagi produsen dan konsumen. Bagi produsen, merek berperan penting sebagai sarana identifikasi produk dan perusahaan, bentuk proteksi hukum, signal jaminan kualitas, sarana menciptakan asosiasi dan makna unik (diferensiasi), sarana keunggulan kompetitif, dan sumber financial returns. Sementara bagi konsumen, merek berperan krusial sebagai identifikasi sumber produk, penetapan tanggungjawab pada produsen atau distributor spesifik, pengurang resiko, penekan biaya pencarian internal dan eksternal, janji atau ikatan khusus dengan produsen, alat simbolis yang memproyeksikan citra diri, dan signal kualitas.

\section{Kepuasan Konsumen}

Keberhasilan sebuah perusahaan bisa dilihat dari kepuasan yang di rasakan konsumen terhadap produk yang ditawarkan, dengan melihat kepuasan konsumen perusahaan bisa mengetahui apakah kinerja dari perusahaan sendiri sudah baik dan sesuai harapan ataukah masih perlu ditingkatkan. Menurut Sangadji dan Sopiah (2013), kepuasan atau ketidakpuasan adalah perasaan senang atau kecewa seseorang yang berasal dari perbandingan antara kesannya terhadap kinerja produk yang riil/aktual dengan kinerja produk yang diharapkan. Menurut Tjiptono dan Chandra (2016:204), "Satisfaction is the good feeling that you have when you achieved something or when something that you wanted to happen"; "the act of fulfilling a need or desire”. Yang berarti kepuasan adalah perasaan baik yang anda dapatkan saat anda mencapai sesuatu atau ketika anda menginginkan sesuatu yang anda inginkan, 
tindakan memenuhi kebutuhan atau keinginan.

\section{Loyalitas Pelanggan}

Secara umum loyalitas diartikan sebagai pembelian ulang yang terus menerus pada merek yang sama, atau dengan kata lain adalah tindakan seseorang yang membeli merek, perhatian hanya pada merek tertentu, dan tidak mencari informasi yang berkaitan dengan merek tersebut. Kualitas produk merupakan seluruh gabungan karakteristik produk dari pemasaran, rekayasa (perencanaan), pembuatan (produk) dan pemeliharaan yang membuat produk yang digunakan memenuhi harapan harapan pelanggan (Kotler dan Keller, 2012). Sedangkan menurut Tjiptono dan Chandra (2012), Kualitas produk merupakan seluruh gabungan karakteristik produk dari pemasaran, rekayasa (perencanaan), pembuatan (produk) dan pemeliharaan yang membuat produk yang digunakan memenuhi harapan harapan pelanggan.

\section{Penelitian Terdahulu}

\begin{tabular}{|c|c|c|c|}
\hline Penulis & Judul & Tahun & Hasil \\
\hline $\begin{array}{l}\text { Osman M. } \\
\text { Karatepe }\end{array}$ & $\begin{array}{l}\text { Service Quality, } \\
\text { Customer } \\
\text { Satisfaction and } \\
\text { Loyalty : The } \\
\text { Moderating Role } \\
\text { of Gender }\end{array}$ & 2011 & 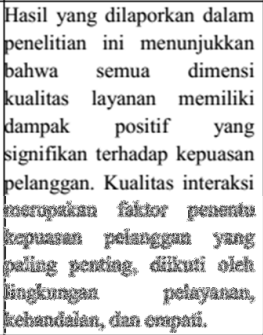 \\
\hline \multirow[t]{2}{*}{$\begin{array}{l}\text { Chasy } \\
\text { Sordiakin }\end{array}$} & 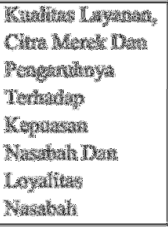 & 2014 & 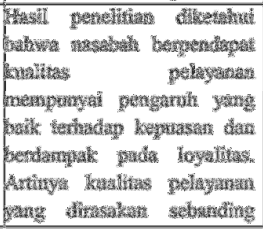 \\
\hline & 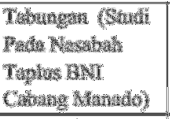 & & 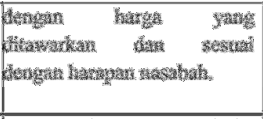 \\
\hline 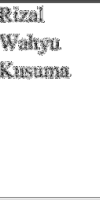 & 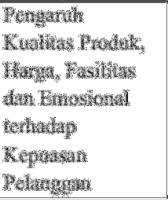 & 2015 & 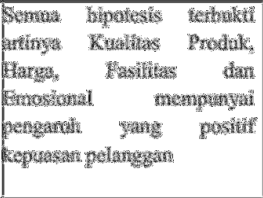 \\
\hline
\end{tabular}

\section{Hipotesis}

H1: Terdapat pengaruh yang positif antara kualitas produk terhadap kepuasan nasabah di Bank BRI Yogyakarta.

H2: Terdapat pengaruh yang positif antara kualitas layanan terhadap kepuasan nasabah di Bank BRI Yogyakarta.

H3: Terdapat pengaruh yang positif antara citra merek terhadap kepuasan nasabah di Bank BRI Yogyakarta.

H4: Terdapat pengaruh yang positif antara kualitas produk, kualitas layanan dan citra merek terhadap kepuasan nasabah di Bank BRI Yogyakarta..

H5: Terdapat pengaruh yang positif antara kualitas produk terhadap loyalitas nasabah di Bank BRI Yogyakarta.

H6: Terdapat pengaruh yang positif antara kualitas layanan terhadap loyalitas nasabah di Bank BRI Yogyakarta.

H7: Terdapat pengaruh yang positif antara citra merek terhadap loyalitas nasabah di Bank BRI Yogyakarta.

H8: Terdapat pengaruh yang positif antara kualitas produk, kualitas layanan dan citra merek terhadap loyalitas nasabah di Bank BRI Yogyakarta.

H9: Terdapat pengaruh yang positif antara kepuasan nasabah terhadap loyalitas nasabah di Bank BRI Yogyakarta.

\section{METODE PENELITIAN}

\section{Populasi dan Sampel}

Populasi adalah wilayah generalisasi yang terdiri dari objek/subjek yang mempunyai kualitas dan karakteristik tertentu yang ditetapkan oleh peneliti untuk dipelajari dan kemudian ditarik kesimpulannya (Sugiyono,). Populasi dalam penelitian ini yaitu semua nasabah dari Bank BRI Yogyakarta. Menurut Sugiyono (2013), sampel adalah bagian dari jumlah dan karakteristik yang dimiliki 
oleh populasi. Sedangkan sampel dalam penelitian ini yaitu sebagian dari jumlah Nasabah dari Bank BRI Yogyakarta.

\section{Definisi Operasional}

1. Variabel Penelitian

Variabel dalam penelitian ini terdiri dari variabel independen (Y) dan variabel dependen $(\mathrm{X})$, yaitu:

Y : Kepuasan Nasabah

$\mathrm{Z}$ : Loyalitas Nasabah

$\mathrm{X}_{1}$ : Kualitas Produk

$\mathrm{X}_{2}$ : Kualitas Layanan

$\mathrm{X}_{3}$ : Citra Merek

\section{Loyalitas Nasabah}

Adapun indiktor loyalitas pelanggan menurut Griffin (2005) adalah

a) Melakukan pembelian secara teratur

b) Membeli antarlini produk dan jasa

c) Mereferensikan kepada orang lain

d) Menunjukkan kekebalan terhadap tarikan

\section{Kepuasan Nasabah}

Adapun indikator yang digunakan dalam menilai kepuasan konsumen adalah (Philip Kotler dan Kevin Lane Keller, 2009) :

a) Mengidentifikasi atribut dan manfaat utama yang dinilai pelanggan.

b) Menilai arti penting kuantitatif dari atribut dan manfaat yang berbeda.

c) Menilai kinerja perusahaan dan pesaing berdasarkan nilai pelanggan yang berbeda dan membandingkannya dengan peringkat arti pentingnya.

d) Mempelajari bagaimana pelanggan dalam segmen tertentu menentukan peringkat kinerja perusahaan terhadap pesaing utama tertentu berdasarkan suatu atribut atau manfaat.

e) Mengamati nilai pelanggan sepanjang waktu.

\section{Kualitas Produk}

Menurut Prawiro Sentono (2004) dalam skripsi Muhammar Arif Setyawan (2015) indikator kualitas produk dalam penelitian ini adalah sebagai berikut:

a) Kesesuaian produk

b) Kualitas produk dapat bersaing

c) Jangka Waktu Ketahanan produk (kualitas kartu ATM/ produk internet banking lain)

d) Kualitas keamanan menggunakan Produk

\section{Kualitas Pelayanan}

Menurut Kotler (2009) kualitas pelayanan memiliki indikator-indikator yaitu sebagai berikut :

a) Kehandalan (Reliability) Yaitu kemampuan melaksanakan jasa yang dijanjikan dengan andal dan akurat. Hal ini berarti jasa yang dikelola harus dilaksanakan dengan konsisten dan cermat. Indikator dari reliabilitas meliputi:

1. Menyediakan jasa pada waktu yang dijanjikan

2. Melaksanakan jasa dengan benar

3. Menyediakan jasa sesuai yang dijanjikan

4. Mempertahankan catatan bebas kesalahan

5. Karyawan yang mempunyai pengetahuan untuk menjawab pertanyaan pelanggan.

b) Ketanggapan (Responsivitas) Ketanggapan adalah kesediaan membantu pelanggan dan memberikan layanan tepat waktu. Hal ini berarti manajemen harus memberikan tanggapan dengan cepat dan kreatif atas permintaan dan masalah konsumen. 1. Layanan tepat waktu bagi pelanggan

2. Kesediaan untuk membantu pelanggan

3. Selalu memberitahu kapan layanan akan dilaksanakan

4. Kesiapan untuk merespons permintaan pelanggan. 
c) Jaminan (Assurance) Jaminan adalah pengetahuan dan kesopanan karyawan serta kemampuan mereka untuk menunjukan kepercayaan dan keyakinan. Jaminan meliputi:

1. Membuat pelanggan merasa aman dalam transaksi mereka

2. Karyawan yang selalu sopan

3. Karyawan yang menanamkan keyakinan pada pelanggan.

d) Empati (Emphaty) Empati yaitu kondisi memperhatikan dan memberikan perhatian pribadi kepada pelanggan. Atau berarti perhatian yang diberikan pemberi jasa pada kliennya. Indikator dari empati meliputi :

1. Karyawan yang menghadapi pelanggan dengan cara yang penuh perhatian

2. Mengutamakan kepentingan terbaik pelanggan.

e) Wujud (Tangible) Wujud adalah penampilan fasilitas fisik, peralatan, personel, dan bahan komunikasi. Wujud meliputi:

1. Peralatan modern

2. Karyawan yang memiliki penampilan rapi dan profesional.

\section{Citra Merek}

Menurut Kotler dan Amstrong (2005) yang dikutip oleh Conny Sondakh (2014), ada 3 indikator citra merek :

a. Kekuatan (strength)

Strength mengarah pada berbagai keunggulan-keunggulan yang dimiliki merek bersangkutan yang bersifat fisik, dan tidak ditemukan pada merek lainnya. Keunggulan merek ini mengacu pada atributatribut fisik atas merek bersangkutan sehingga bisa dianggap sebagai sebuah kelebihan dibandingkan merek lainnya. b. Keunikan (uniqueness)

Sementara uniqueness adalah kemampuan untuk membedakan sebuah merek diantara merek-merek lainnya. Kesan unik ini muncul dari atribut produk, kesan unik berarti terdapat diferensiasi antara produk satu dengan produk lainnya.

c. Kesenangan (Favourable)

Favourable mengarah pada kemampuan merek tersebut untuk mudah diingat oleh pelanggan. Termasuk dalam kelompok favourable ini antara lain: kemudahan merek produk untuk diucapkan, kemampuan mereka untuk tetap diingat pelanggan, maupun kesesuaian antara kesan merek dibenak pelanggan dengan citra yang diinginkan perusahaan atas merek.

\section{Uji Instrumen}

1. Uji Validitas

Validitas adalah suatu ukuran yang menunjukkan tingkat kevalidan dan kesahihan suatu instrumen". Pengertian validitas tersebut menunjukan ketepatan dan kesesuaian alat ukur yang digunakan untuk mengukur variabel. Penghitungan uji validitas ini menggunakan pendekatan CFA (Confirmatory Factor Analisys). Dalam Uji Validitas tersebut indikator indikator yang telah ditentukan akan di uji menggunakan pendekatan CFA. Indikator tersebut bisa dikatakan valid jika nilai Factor Loading di atas 0,5 dan dapat membentuk dalam satu komponen.

2. Uji Reliabilitas

Menurut Sugiono (2005) Pengertian Reliabilitas adalah serangkaian pengukuran atau serangkaian alat ukur yang memiliki konsistensi bila pengukuran yang dilakukan dengan alat ukur realibilitas tersebut dilakukan secara berulang. Kriteria dikatakan reliabel atau dapat dipercaya ditentukan 
dengan nilai $\alpha$ (cronbanch alpha) lebih besar sama dengan nilai batas yang ditentukan atau standarisasi sebesar 0,6. Standarisasi merupakan batas yang digunakan untuk mengukur tingkat konsistensi suatu variabel independent mempengaruhi variabel dependent. Ghozali (2009) menyatakan bahwa reliabilitas adalah alat untuk mengukur suatu kuesioner yang merupakan indikator dari peubah atau konstruk. Suatu kuesioner dikatakan reliabel atau handal jika jawaban seseorang terhadap pernyataan adalah konsisten atau stabil dari waktu ke waktu. Reliabilitas suatu test merujuk pada derajat stabilitas, konsistensi, daya prediksi, dan akurasi. Pengukuran yang memiliki reliabilitas yang tinggi adalah pengukuran yang dapat menghasilkan data yang reliabel

\section{Teknik Analisis Data}

1. Analisis Regresi Berganda

Regresi Linear Berganda digunakan oleh peneliti. Bila peneliti bermaksud meramalkan bagaimana keadaaan (naikturunya) variabel dependen bila dua atau lebih independen sebagai variabel independen (Sugiyono, 2008). Sehingga penelitian ini dapat dirumuskan dengan $\mathrm{Y}_{1}=\mathrm{a}+\mathrm{b}_{1} \mathrm{X}_{1}+\mathrm{b}_{2} \mathrm{X}_{2}+\mathrm{b}_{3} \mathrm{X}_{3}+\mathrm{e}$

Keterangan:

$\mathrm{Y}=$ (Variabel dependen $)$

$\mathrm{a}=$ Konstanta

$\mathrm{b}=$ Koefisien

$\mathrm{X}=$ Variabel Independen

e $=$ Standar Error

\section{Uji Hipotesis}

1. Uji Parsial (Uji T)

Uji $\mathrm{t}$ digunakan untuk menguji secara parsial masing-masing variabel. Hasil uji $t$ dapat dilihat pada tabel coefficients pada kolom sig (significance). Jika probabilitas nilai $\mathrm{t}$ atau signifikansi $<0,05$, maka dapat dikatakan bahwa terdapat pengaruh antara variabel bebas terhadap variabel terikat secara parsial. Namun, jika probabilitas nilai $t$ atau signifikansi $>$
0,05, maka dapat dikatakan bahwa tidak terdapat pengaruh yang signifikan antara masing-masing variabel bebas terhadap variabel terikat.

Hipotesis yang diajukan dan akan diuji adalah sebagai berikut:

1) H01: Tidak ada pengaruh positif kualitas produk terhadap kepuasan nasabah di Bank BRI Yogyakarta.

Ha1: Ada pengaruh positif kualitas produk terhadap kepuasan nasabah di Bank BRI Yogyakarta.

2) H02: Tidak ada pengaruh positif kualitas layanan terhadap kepuasan nasabah di Bank BRI Yogyakarta.

Ha2: Ada pengaruh positif kualitas layanan terhadap kepuasan nasabah di Bank BRI Yogyakarta.

3) H03: Tidak ada pengaruh positif citra merek terhadap kepuasan nasabah di Bank BRI Yogyakarta.42

Ha3: Ada pengaruh positif citra merek terhadap kepuasan nasabah di Bank BRI Yogyakarta.

4) H05: Tidak ada pengaruh positif kualitas produk terhadap loyalitas nasabah di Bank BRI Yogyakarta.

Ha5: Ada pengaruh positif kualitas produk terhadap loyalitas nasabah di Bank BRI Yogyakarta.

5) H06: Tidak ada pengaruh positif kualitas layanan terhadap loyalitas nasabah di Bank BRI Yogyakarta.

Ha6: Ada pengaruh positif kualitas layanan terhadap loyalitas nasabah di Bank BRI Yogyakarta.

6) H07: Tidak ada pengaruh positif citra merek terhadap loyalitas nasabah di Bank BRI Yogyakarta. 
Ha7: Ada pengaruh positif citra merek terhadap loyalitas nasabah di Bank BRI Yogyakarta.

7) H09: Tidak ada pengaruh positif kepuasan nasabah terhadap loyalitas nasabah di Bank BRI Yogyakarta.

Ha9: Ada pengaruh positif kepuasan terhadap loyalitas nasabah di Bank BRI Yogyakarta.

2. Uji Simultan (Uji F)

Uji $F$ digunakan untuk mengetahui pengaruh variabel bebas secara bersama-sama (simultan) terhadap variabel terikat. Signifikan berarti hubungan yang terjadi dapat berlaku untuk populasi. Penggunaan tingkat signifikansinya beragam, tergantung keinginan peneliti, yaitu $0,01(1 \%)$; $0,05(5 \%)$ dan $0,10(10 \%)$. Hasil uji $\mathrm{F}$ dilihat dalam tabel ANOVA dalam kolom sig. Sebagai contoh, kita menggunakan taraf signifikansi 5\% $(0,05)$, jika nilai probabilitas $<0,05$, maka dapat dikatakan terdapat pengaruh yang signifikan secara bersama-sama antara variabel bebas terhadap variabel terikat. Namun, jika nilai signifikansi > 0,05 maka tidak terdapat pengaruh yang signifikan secara bersama-sama antara variabel bebas terhadap variabel terikat. Hipotesis yang diajukan dan akan diuji adalah sebagai berikut:

1) $\mathrm{HO}_{4}$ : Tidak ada pengaruh positif kualitas produk, kualitas layanan dan citra merek terhadap kepuasan nasabah di Bank BRI Yogyakarta.

Ha4 : Ada pengaruh positif kualitas produk, kualitas layanan dan citra merek terhadap kepuasan nasabah di Bank BRI Yogyakarta.

2) $\mathrm{H}_{8}$ : Tidak ada pengaruh positif kualitas produk, kualitas layanan dan citra merek terhadap loyalitas nasabah di Bank BRI Yogyakarta. Ha8: Ada pengaruh positif kualitas produk, kualitas layanan dan citra merek terhadap loyalitas nasabah di Bank BRI Yogyakarta.

3. Uji Koefisien Determinasi

Uji ini bertujuan untuk menentukan proporsi atau persentase total variasi dalam variabel terikat yang diterangkan oleh variabel bebas. Apabila analisis yang digunakan adalah regresi sederhana, maka yang digunakan adalah nilai R Square. Namun, apabila analisis yang digunakan adalah regresi berganda, maka yang digunakan adalah Adjusted R Square. Hasil perhitungan Adjusted $\mathrm{R}_{2}$ dapat dilihat pada output Model Summary. Pada kolom Adjusted $\mathrm{R}_{2}$ dapat diketahui berapa persentase yang dapat dijelaskan oleh variabel-variabel bebas terhadap variabel terikat. Sedangkan sisanya dipengaruhi atau dijelaskan oleh variabel-variabel lain yang tidak dimasukkan dalam model penelitian.

\section{HASIL PENELITIAN DAN PEMBAHASAN}

\section{Hasil Penelitian}

1. Hasil Uji Validitas

\section{a. Uji Validitas Variabel Kualitas} Produk (KP/X1)

Tabel Hasil Uji Validitas Kualitas Produk

\begin{tabular}{|c|c|c|}
\hline & \multicolumn{2}{|c|}{ Component } \\
\hline & 1 & 2 \\
\hline KP1 & 0.463 & -0.690 \\
\hline KP2 & 0.614 & -0.176 \\
\hline KP3 & 0.784 & -0.187 \\
\hline KDA & 0.766 & 0.395 \\
\hline nes & 16.11 & 6. \\
\hline 5 & ars & ThIS \\
\hline
\end{tabular}

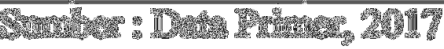

Dari hasil output diatas terlihat membentuk 2 component sedangkan yang diharapkan hanya membentuk 
1 component saja. Maka proses harus diulang dengan mengeluarkan indikator-indikator yang dianggap tidak valid yaitu yang memiliki MSA (Measure of Sampling Adequacy) paling kecil dengan memperhatikan tabel Antiimages Matrices pada output SPSS dibagian Anti-images Corelation. Terlihat bahwa indikator KP1 memiliki $M S A=$,545. Dengan demikian indikator tersebut yaitu pertanyaan nomor 1 dari variabel kualitas produk dikeluarkan dari analisis karena dinyatakan tidak valid.

Table 4.2

Tabel Hasil Uji Validitas Kualitas Produk

\begin{tabular}{|c|c|}
\hline & Component \\
\hline & 1 \\
\hline KN2 & 0.609 \\
\hline IKr. & 阆 \\
\hline 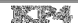 & 6. \\
\hline 5nds & 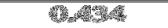 \\
\hline 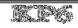 & arras \\
\hline
\end{tabular}

Jadi, dalam variabel kualitas produk hanya ada item KP2, KP3, KP4, KP5, dan KP6. Sehingga kelima item pernyataan tersebut dianggap valid dengan memilki nilai factor loading > 0,50 .

\section{b. Uji Validitas Variabel Kualitas Layanan (KL/X2) \\ Tabel 4.3}

Tabel Hasil Uji Validitas Kualitas Layanan

\begin{tabular}{|c|c|c|c|}
\hline \multirow{2}{*}{} & \multicolumn{3}{|c|}{ Component } \\
\cline { 2 - 4 } & 1 & 2 & 3 \\
\hline KL1 & 0.613 & -0.472 & 0.324 \\
\hline KL2 & 0.676 & 0.007 & 0.064 \\
\hline KL3 & 0.343 & 0.535 & 0.558 \\
\hline KL4 & 0.485 & 0.627 & -0.188 \\
\hline KL5 & 0.492 & 0.342 & -0.639 \\
\hline KL6 & 0.708 & 0.219 & 0.080 \\
\hline KL7 & 0.711 & 0.083 & -0.170 \\
\hline KL8 & 0.692 & -0.067 & 0.453 \\
\hline KL9 & 0.529 & -0.557 & -0.257 \\
\hline KL10 & 0.677 & -0.361 & -0.206 \\
\hline
\end{tabular}

Dari hasil output diatas terlihat membentuk 3 component sedangkan yang diharapkan hanya membentuk 1 component saja. Maka proses harus diulang dengan mengeluarkan indikator-indikator yang dianggap tidak valid yaitu yang memiliki MSA (Measure of Sampling Adequacy) paling kecil dengan memperhatikan tabel Antiimages Matrices pada output SPSS dibagian Anti-images Corelation. Terlihat bahwa indikator KL5 memiliki $M S A=$ ,452. Dengan demikian indikator tersebut yaitu pernyataan nomor 5 dari variabel kualitas layanan dikeluarkan dari analisis karena dinyatakan tidak valid.

Tabel 4.4

Tabel Hasil Uji Validitas Kualitas Layanan

\begin{tabular}{|c|c|c|}
\hline & \multicolumn{2}{|c|}{ Component } \\
\hline & 1 & 2 \\
\hline KL1 & 0.663 & -0.345 \\
\hline KL2 & 0.666 & 0.030 \\
\hline Resthas & (20) 3 & andsans \\
\hline 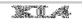 & 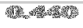 & $0.5 \%$ \\
\hline 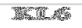 & 6. & arro \\
\hline 5 & D. & When \\
\hline 2EIII S & and & 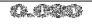 \\
\hline 5 & 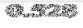 & - \\
\hline refor. & Whit & No beres \\
\hline
\end{tabular}

Dari hasil output diatas terlihat membentuk 2 component sedangkan yang diharapkan hanya membentuk 1 component saja. Maka proses harus diulang dengan mengeluarkan indikator-indikator yang dianggap tidak valid yaitu yang memiliki MSA (Measure of Sampling Adequacy) paling kecil dengan memperhatikan tabel Antiimages Matrices pada output SPSS dibagian Anti-images Corelation. Terlihat bahwa indikator KL3 memiliki $M S A=$ ,641. Dengan demikian indikator tersebut yaitu pernyataan nomor 3 dari variabel 
Tabel 4.5

Tabel Hasil Uji Validitas Kualitas Layanan

\begin{tabular}{|c|c|c|}
\hline \multirow{2}{*}{} & \multicolumn{2}{|c|}{ Component } \\
\cline { 2 - 3 } KL1 & 1 & 2 \\
\hline KL2 & 0.680 & -0.377 \\
\hline KL4 & 0.410 & -0.015 \\
\hline KL6 & 0.700 & 0.719 \\
\hline KL7 & 0.691 & 0.421 \\
\hline KL8 & 0.711 & 0.229 \\
\hline KL9 & 0.566 & -0.018 \\
\hline KL10 & 0.723 & -0.558 \\
\hline
\end{tabular}

Dari hasil output diatas terlihat masih membentuk 2 component sedangkan yang diharapkan hanya membentuk 1 component saja. Maka proses harus diulang dengan mengeluarkan indikator-indikator yang dianggap tidak valid yaitu yang memiliki MSA (Measure of Sampling Adequacy) paling kecil dengan memperhatikan tabel Antiimages Matrices pada output SPSS dibagian Anti-images Corelation. Terlihat bahwa indikator KL4 memiliki $M S A=$,664. Dengan demikian indikator tersebut yaitu pernyataan nomor 4 dari variabel

Tabel 4.6

Tabel Hasil Uji Validitas Kualitas Layanan

\begin{tabular}{|c|c|c|}
\hline \multirow{2}{*}{} & \multicolumn{2}{|c|}{ Component } \\
\cline { 2 - 3 } & 1 & 2 \\
\hline KL1 & 0.718 & 0.124 \\
\hline KL2 & 0.650 & 0.220 \\
\hline KL6 & 0.676 & -0.575 \\
\hline KL7 & 0.680 & -0.474 \\
\hline KL8 & 0.713 & -0.117 \\
\hline KL9 & 0.603 & 0.500 \\
\hline KL10 & 0.723 & 0.359 \\
\hline \multicolumn{2}{|c|}{ Sumber : Data Primer, 2017} \\
\hline
\end{tabular}

Dari hasil output diatas terlihat masih membentuk 2 component sedangkan yang diharapkan hanya membentuk 1 component saja. Maka proses harus diulang dengan mengeluarkan indikator-indikator yang dianggap tidak valid yaitu yang memiliki MSA (Measure of Sampling Adequacy) paling kecil dengan memperhatikan tabel Antiimages
Matrices pada output SPSS dibagian Anti-images Corelation. Terlihat bahwa indikator KL7 memiliki $M S A=, 706$. Dengan demikian indikator tersebut yaitu pernyataan nomor 7 dari variabel

Tabel 4.7

Tabel Hasil Uji Validitas Citra Merek Kualitas Layanan

\begin{tabular}{|l|c|}
\hline & Component \\
\cline { 2 - 2 } & 1 \\
\hline KL1 & 0.733 \\
\hline KL2 & 0.711 \\
\hline KL6 & 0.618 \\
\hline KL8 & 0.721 \\
\hline KL9 & 0.623 \\
\hline KL10 & 0.747 \\
\hline
\end{tabular}

Setelah membentuk satu komponen, dalam variabel lingkungan kerja hanya ada item pernyataan yang teridir KL1, KL2, KL6, KL8, KL9 dan KL10. Sehingga keenam item pernyataan tersebut dianggap valid dengan memilki nilai factor loading > 0,50 .

\section{c. Uji Validitas Variabel Citra Merek (CM/X3) \\ Tabell 4.8}

Tabel Hasil Uji Validitas Citra Merek

\begin{tabular}{|c|c|c|}
\hline \multirow{2}{*}{} & \multicolumn{2}{|c|}{ Component } \\
\cline { 2 - 3 } & 1 & 2 \\
\hline CM1 & 0.708 & 0.414 \\
\hline CM2 & 0.735 & -0.075 \\
\hline CM4 & 0.610 & -0.277 \\
\hline CM5 & 0.723 & -0.070 \\
\hline CM6 & 0.584 & -0.534 \\
\hline \multicolumn{2}{|c|}{ Sumber : Data Primer, 2017 } \\
\hline
\end{tabular}

Dari hasil output diatas terlihat membentuk 2 component sedangkan yang diharapkan hanya membentuk 1 component saja. Maka proses harus diulang dengan mengeluarkan indikatorindikator yang dianggap tidak valid yaitu yang memiliki MSA (Measure of Sampling Adequacy) paling kecil dengan memperhatikan tabel Antiimages Matrices pada output SPSS dibagian Anti-images Corelation. Terlihat bahwa indikator CM6 memiliki $M S A=$,661. Dengan demikian indikator tersebut yaitu 
pernyataan nomor 6 dari variabel citra merek dikeluarkan dari analisis karena dinyatakan tidak valid.

Tabel 4.9

Tabel Hasil Uji Validitas Citra Merek

\begin{tabular}{|c|c|}
\hline & Component \\
\hline & 1 \\
\hline Cad & 2670 \\
\hline 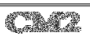 & 12. \\
\hline 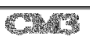 & 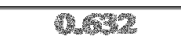 \\
\hline maseras & Thas \\
\hline Whas & 264.45 \\
\hline
\end{tabular}

Setelah membentuk satu komponen, dalam variabel citra merek hanya ada item pernyataan yang teridir CM1, CM2, CM3, CM4 dan CM5. Sehingga kelima item pernyataan tersebut dianggap valid dengan memilki nilai factor loading $>0,50$.

\section{d. Uji Validitas Variabel Loyalitas Nasabah (LN/Y) \\ Tabel 4.10}

Tabel Hasil Uji Validitas Loyalitas Nasabah

\begin{tabular}{|c|c|}
\hline & Component \\
\hline & 1 \\
\hline LN1 & 0.596 \\
\hline TNR & 195tos \\
\hline IIVIV & 4. \\
\hline LWNS & Whys \\
\hline CDIs & 582 \\
\hline
\end{tabular}

Setelah membentuk satu komponen, dalam variabel loyalitas nasabah terdapat item pernyataan yang terdiri LN1, LN2, LN3, LN4, dan LN5. Sehingga kelima item pernyataan tersebut dianggap valid dengan memilki nilai factor loading $>$ 0,50 .

\section{e. Uji Validitas Variabel Kepuasan Nasabah (KN/Z) \\ Tabel 4.11}

Tabel Hasil Uji Validitas Kepuasan Nasabah

\begin{tabular}{|c|c|c|}
\hline & \multicolumn{2}{|c|}{ Component } \\
\hline & 1 & 2 \\
\hline KN1 & 0.817 & -0.291 \\
\hline Nowe & 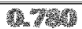 & 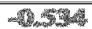 \\
\hline nexy & 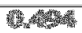 & 14. \\
\hline 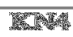 & 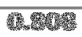 & 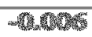 \\
\hline Why & 7. & 7. \\
\hline
\end{tabular}

Dari hasil output diatas terlihat membentuk 2 component sedangkan yang diharapkan hanya membentuk 1 component saja. Maka proses harus diulang dengan mengeluarkan indikator-indikator yang dianggap tidak valid yaitu yang memiliki MSA (Measure of Sampling Adequacy) paling kecil dengan memperhatikan tabel Antiimages Matrices pada output SPSS dibagian Anti-images Corelation. Terlihat bahwa indikator $\mathrm{KN} 2$ memiliki $M S A=$ ,517. Dengan demikian indikator tersebut yaitu pernyataan nomor 2 dari variabel kepuasan nasabah dikeluarkan dari analisis karena dinyatakan tidak valid.

Tabel 4.12

Tabel Hasil Uji Validitas Kepuasan Nasabah

\begin{tabular}{|c|c|}
\hline & Component \\
\hline & 1 \\
\hline 㢣WNI & 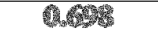 \\
\hline KaN & 6.62 \\
\hline 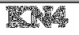 & $\sqrt{9772}$ \\
\hline IIIS & 721 \\
\hline
\end{tabular}

Setelah membentuk satu komponen, dalam variable kepuasan nasabah hanya ada item pernyataan yang teridiri KN1, KN3, KN4 dan KN5. Sehingga keempat item pernyataan tersebut dianggap valid dengan memilki nilai factor loading $>0,50$. 


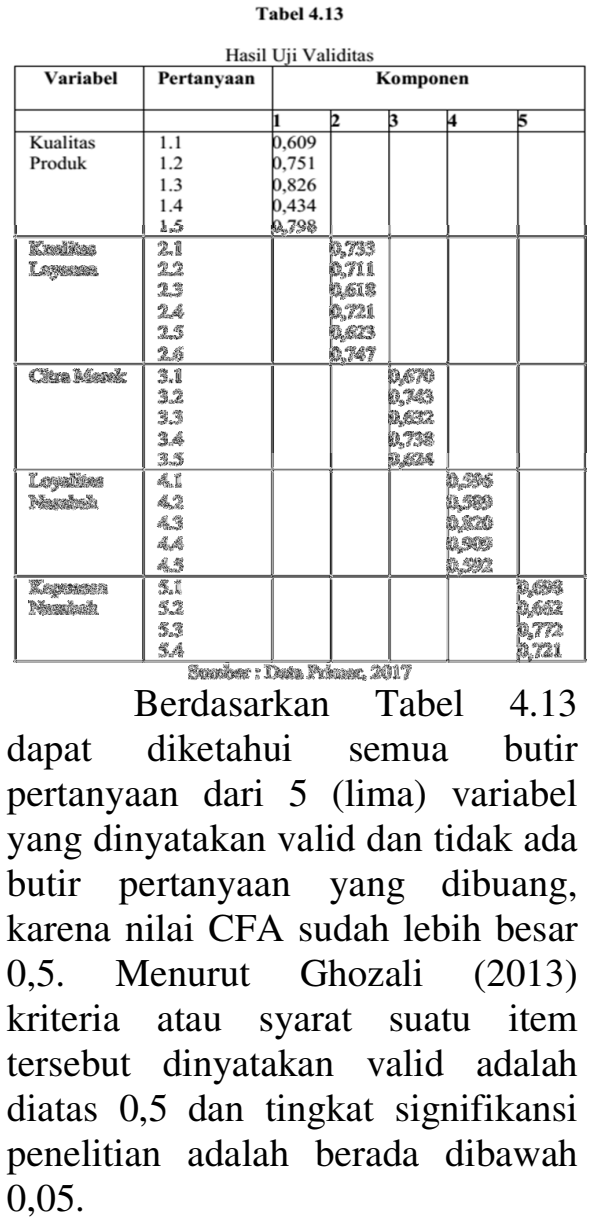

2. Hasil Uji Reliabilitas

\begin{tabular}{|c|c|c|c|}
\hline No & Variabel & $\begin{array}{c}\text { Croncbanch's } \\
\text { Alpha }\end{array}$ & Keterangan \\
\hline 1 & Kualitas Produk ( $\mathrm{X}_{1}$ ) & 0,688 & Reliabel \\
\hline 2 & Kualitas Layanan $\left(\mathrm{X}_{2}\right)$ & 0,791 & Reliabel \\
\hline 3 & catra & 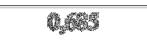 & 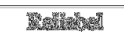 \\
\hline$\overline{3}$ & 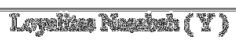 & 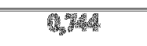 & 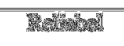 \\
\hline 3 & 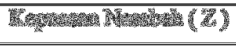 & pro & 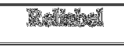 \\
\hline
\end{tabular}

Dari tabel 4.13 diatas maka hasil dari uji reliabilitas dapat dijelaskan sesuai dengan nilai Croncbanch's Alpha variabel. Berikut penjelasannya:

Kualitas produk pada loyalitas nasabah, nilai yang dihasilkan oleh variabel ini sebesar 0,688 dimana sesuai ketentuan nilai 0,688 lebih besar dari 0,60 sehingga hasil dari variabel tanggap dalam pengujian yaitu reliabel. Dalam variabel ini setiap butir pernyataan dan jawaban konsisten.

Kualitas layanan pada loyalitas nasabah, nilai yang dihasilkan oleh variabel ini sebesar 0,791 dimana sesuai ketentuan nilai 0,791 lebih besar dari 0,60 sehingga hasil dari variabel tanggap dalam pengujian yaitu reliabel. Dalam variabel ini setiap butir pernyataan dan jawaban konsisten.

Citra merek pada loyalitas nasabah, nilai yang dihasilkan oleh variabel ini sebesar 0,685 dimana sesuai ketentuan nilai 0,685 lebih besar dari 0,60 sehingga hasil dari variabel tanggap dalam pengujian yaitu reliabel. Dalam variabel ini setiap butir pernyataan dan jawaban konsisten.

Loyalitas nasabah, nilai yang dihasilkan oleh variabel ini sebesar 0,744 dimana sesuai ketentuan nilai 0,744 lebih besar dari 0,60 sehingga hasil dari variabel tanggap dalam pengujian yaitu reliabel. Dalam variabel ini setiap butir pernyataan dan jawaban konsisten.

Kepuasan nasabah, nilai yang dihasilkan oleh variabel ini sebesar 0,739 dimana sesuai ketentuan nilai 0,739 lebih besar dari 0,60 sehingga hasil dari variabel tanggap dalam pengujian yaitu reliabel. Dalam variabel ini setiap butir pernyataan dan jawaban konsisten

\section{Hasil Uji Regresi Linier Berganda}

Uji Regresi Linier Berganda Model I

Hasil Uji Hipotesis pada Seluruh Variabel Penelitian

\begin{tabular}{|c|c|c|}
\hline \multirow{2}{*}{ Model } & $\begin{array}{c}\text { Unstandarized } \\
\text { Coefisient }\end{array}$ & \multirow{2}{*}{ Sig. } \\
\cline { 2 - 2 } & $\mathrm{B}$ & \\
\hline 1 (Constant) & 0,674 & 0,667 \\
\hline $\mathrm{X}_{1}$ & 0,165 & 0,008 \\
\hline $\mathrm{X}_{2}$ & 0,148 & 0,001 \\
\hline $\mathrm{X}_{3}$ & 0,167 & 0,570 \\
\hline
\end{tabular}

Sumber : Data Primer, 2017

$\mathrm{Y}=\mathbf{a}+\mathrm{B}_{1} \mathbf{X}_{1}+\mathrm{B}_{2} \mathrm{X}_{2}+\mathrm{B}_{3} \mathrm{X}_{3}+\mathrm{e}$

$Y=0,674+0,165 X_{1}+0,148 X_{2}+$ $0,167 X_{3}+e$ 
Setiap nilai dari persamaan regresi diatas dapat diinterpretasikan yaitu : $\mathrm{a}=0,674$ merupakan nilai constant. Jika nilai dari $\mathrm{X}_{1}, \mathrm{X}_{2}$, dan $\mathrm{X}_{3}$ dimisalkan 0 maka nilai dari kepuasan nasabah akan menurun sebesar 0,674.

$b_{1}=0,165$ koefisien bernilai positif artinya terjadi hubungan positif antara kualitas produk $\left(\mathrm{X}_{1}\right)$ dengan kepuasan nasabah (Z). Jika nilai kualitas produk (X1) semakin besar maka nilai kepuasan nasabah (Z) akan besar. Koefisien kualitas produk $\left(\mathrm{X}_{1}\right)$ sebesar 0,165 artinya jika nilai variabel independen lainnya tetap dan jika variabel kualitas produk $\left(\mathrm{X}_{1}\right)$ mengalami kenaikan 1 satuan maka kepuasan nasabah (Z) naik sebesar 0,165 .

$\mathrm{b}_{2}=0,148$ koefisien bernilai positif artinya terjadi hubungan positif antara kualitas layanan $\left(\mathrm{X}_{2}\right)$ dengan kepuasan nasabah (Z). Jika nilai kualitas layanan $\left(\mathrm{X}_{2}\right)$ semakin besar maka nilai kepuasan nasabah (Z) akan besar. Koefisien kualitas layanan $\left(\mathrm{X}_{2}\right)$ sebesar 0,148 artinya jika nilai variabel independen lainnya tetap dan jika variabel kualitas layanan $\left(\mathrm{X}_{2}\right)$ mengalami kenaikan 1 satuan maka kepuasan nasabah (Z) naik sebesar 0,148 .

$\mathrm{b}_{3}=0,167$ koefisien bernilai positif artinya terjadi hubungan positif antara citra merek (X3) dengan kepuasan nasabah (Z). Jika nilai citra merek (X3) semakin besar maka nilai kepuasan nasabah (Z) akan besar. Koefisien citra merek (X) sebesar 0,167 artinya jika nilai variabel independen lainnya tetap dan jika variabel citra merek (X3) mengalami kenaikan 1 satuan maka kepuasan nasabah $(Z)$ naik sebesar 0,167 . b. Analisis Regresi Berganda model II Hasil Uji Hipotesis pada Seluruh Variabel Penelitian

\begin{tabular}{|c|c|c|}
\hline \multirow{2}{*}{ Model } & $\begin{array}{c}\text { Unstandarized } \\
\text { Coefisient }\end{array}$ & \multirow{2}{*}{ Sig. } \\
\cline { 2 - 2 } & $\mathrm{B}$ & \\
\hline 1 (Constant) & 1,043 & 0,083 \\
\hline $\mathrm{X} 1$ & 0,050 & 0,734 \\
\hline $\mathrm{X} 2$ & 0,435 & 0,001 \\
\hline $\mathrm{X} 3$ & 0,121 & 0,411 \\
\hline
\end{tabular}

$\mathrm{Y}=\mathbf{a}+\mathrm{B}_{1} \mathrm{X}_{1}+\mathrm{B}_{2} \mathrm{X}_{2}+\mathrm{B}_{3} \mathrm{X}_{3}+\mathrm{e}$

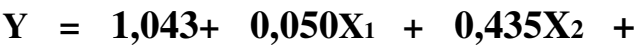
$0,121 X_{3}+e$

Setiap nilai dari persamaan regresi diatas dapat diinterpretasikan yaitu : $\mathrm{a}=1,043$ merupakan nilai constant. Jika nilai dari $\mathrm{X} 1, \mathrm{X} 2$, dan $\mathrm{X} 3$ dimisalkan 0 maka nilai dari loyalitas nasabah akan menurun sebesar 1,043. $\mathrm{b}_{1}=0,050$ koefisien bernilai positif artinya terjadi hubungan positif antara kualitas produk ( $\left.\mathrm{X}_{1}\right)$ dengan loyalitas nasabah (Y). Jika nilai kualitas produk $\left(\mathrm{X}_{1}\right)$ semakin besar maka nilai loyalitas nasabah (Y) akan besar. Koefisien kualitas produk ( $\left.\mathrm{X}_{1}\right)$ sebesar 0,050 artinya jika nilai variabel independen lainnya tetap dan jika variabel kualitas produk (X1) mengalami kenaikan 1 satuan maka loyalitas nasabah (Y) naik sebesar 0,050 .

$\mathrm{b}_{2}=0,435$ koefisien bernilai positif artinya terjadi hubungan positif antara kualitas layanan ( $\left.\mathrm{X}_{2}\right)$ dengan loyalitas nasabah (Y). Jika nilai kualitas layanan $\left(\mathrm{X}_{2}\right)$ semakin besar maka nilai loyalitas nasabah (Y) akan besar. Koefisien kualitas layanan $\left(\mathrm{X}_{2}\right)$ sebesar 0,435 artinya jika nilai variabel independen lainnya tetap dan jika variabel kualitas layanan $\left(\mathrm{X}_{2}\right)$ mengalami kenaikan 1 satuan maka loyalitas nasabah (Y) naik sebesar 0,435 .

$\mathrm{b}_{3}=0,121$ koefisien bernilai positif artinya terjadi hubungan positif antara citra merek $\left(\mathrm{X}_{3}\right)$ dengan loyalitas 
nasabah (Y). Jika nilai citra merek (X3) semakin besar maka nilai loyalitas nasabah (Y) akan besar. Koefisien citra merek (X3) sebesar 0,121 artinya jika nilai variabel independen lainnya tetap dan jika variabel citra merek (X3) mengalami kenaikan 1 satuan maka loyalitas nasabah (Y) naik sebesar 0,121 .

\section{Uji Mediasi}

a. Pengaruh kualitas produk terhadap loyalitas dengan dimediasi kepuasan nasabah

Untuk melakukan pengujian tersebut menggunakan analisis jalur dengan membandingkan pengaruh langsung kualitas produk terhadap loyalitas nasabah dengan pengaruh tidak langsung melalui kepuasan nasabah sebagai variabel mediasi. Pengujian dilakukan dengan tahapan langkah sebagai berikut: Pengaruh langsung.

$\mathrm{X}_{1}$ terhadap $\mathrm{Y}$ : 0,046
Pengaruh tidak langsung
$\mathrm{X}_{1}$ ke Zke $\mathrm{Y}$
Sehingga dapat disimpulkan
dari hasil pengujian lebih
mendasarkan pada ketentuan
dimana pengaruh langsung lebih
kecil dibandingkan pengaruh tidak
langsung, maka dinyatakan bahwa
kepuasan nasabah sebagai variabel
mediasi.

Kepuasan Nasabah dalam model penelitian ini memediasi hubungan antara kualitas produk terhadap loyalitas nasabah jasa perbankan Bank BRI Yogyakarta. Kualitas produk berpengaruh positif dan signifikan secara langsung terhadap loyalitas nasabah melalui.

b. Pengaruh kualitas layanan terhadap loyalitas nasabah dengan dimediasi kepuasan nasabah untuk melakukan pengujian tersebut menggunakan analisis jalur dengan membandingkan pengaruh langsung kualitas layanan terhadap loyalitas nasabah dengan pengaruh tidak langsung melalui kepuasan nasabah sebagai variabel mediasi.

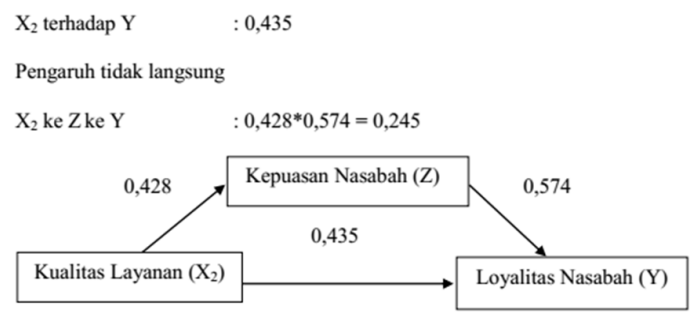

Sehingga dapat disimpulkan dari hasil pengujian lebih mendasarkan pada ketentuan dimana pengaruh tidak langsung lebih kecil dibandingkan pengaruh langsung, maka dinyatakan bahwa kepuasan nasabah tidak memediasi. Kepuasan nasabah dalam model penelitian ini tidak memediasi hubungan antara kualitas layanan terhadap loyalitas nasabah jasa perbankan Bank BRI Yogyakarta. kualitas layanan berpengaruh negatif signifikan secara langsung terhadap loyalitas nasabah melalui kepuasan nasabah. Meskipun nilai pengaruh langsung lebih besar dibandingkan dengan nilai pengaruh langsungnya.

Pengaruh citra merek terhadap terhadap loyalitas nasabah dengan dimediasi kepuasan nasabah Untuk melakukan pengujian tersebut menggunakan analisis jalur dengan membandingkan pengaruh langsung citra merek terhadap loyalitas nasabah dengan pengaruh tidak langsung melalui kepuasan nasabah sebagai variabel mediasi.

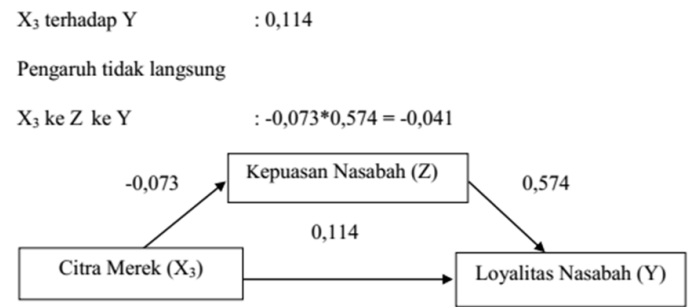

Sehingga dapat disimpulkan dari hasil pengujian lebih mendasarkan pada ketentuan dimana pengaruh langsung lebih besar dibandingkan pengaruh tidak 
langsung, maka dinyatakan bahwa kepuasan nasabah tidak sebagai variabel mediasi. Kepuasan nasabah dalam model penelitian ini tidak memediasi hubungan antara Citra Merek terhadap loyalitas nasabah jasa perbankan Bank BRI Yogyakarta. Citra Merek berpengaruh negatif signifikan secara langsung terhadap loyalitas nasabah melalui kepuasan nasabah. Meskipun nilai pengaruh langsung lebih besar dibandingkan dengan nilai pengaruh tidak langsungnya.

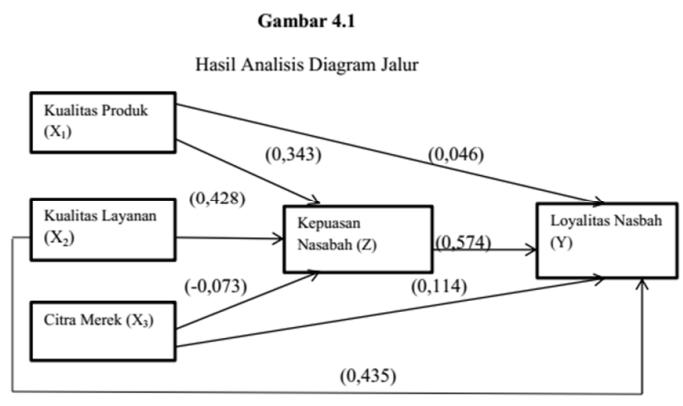

4. Hasil Uji Parsial (Uji T)

Hasil Uji Signifikansi Parsial (Uji T)

\begin{tabular}{|c|c|}
\hline \multirow{2}{*}{ Variabel } & Hasil Uji \\
\cline { 2 - 2 } & Sig. \\
\hline Kualitas Produk & 0,008 \\
\hline Kualitas Layanan & 0,001 \\
\hline Citra Merek & 0,570 \\
\hline
\end{tabular}

Sumber : Dala Primer, 2017

1) Variabel kualitas produk mempunyai nilai signifikan $0,008<0,05$. Maka dapat disimpulkan bahwa secara individual variabel kualitas produk berpengaruh secara signifikan terhadap variabel kepuasan nasabah.

2) Variabel kualitas layanan mempunyai nilai signifikan 0,001>0,05. Maka dapat disimpulkan bahwa secara individual variabel kualitas layanan berpengaruh secara signifikan terhadap variabel kepuasan nasabah.
3) Variabel citra merek mempunyai nilai signifikan 0,570>0,05. Maka dapat disimpulkan bahwa secara individual variabel citra merek tidak berpengaruh secara signifikan terhadap variabel kepuasan nasabah.

b. Uji t model II

Uji t digunakan untuk mengetahui berapa besar atau signifikansi pengaruh variabel independent ( $\mathrm{X}_{1}$ : Kualitas Produk, $\mathrm{X}_{2}$ : Kualitas Layanan, $\mathrm{X}_{3}$ : Citra Merek) secara parsial atau individual terhadap variabel dependent (Y : Loyalitas Nasabah).

Hasil Uji Signifikansi Parsial (Uji T)

\begin{tabular}{|c|c|}
\hline \multirow{2}{*}{ Vaxizbel } & Hasil Uji \\
\hline & Sigig. \\
\hline Kwallas Prodak & 0,734 \\
\hline 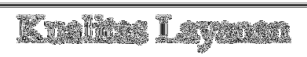 & 9001. \\
\hline 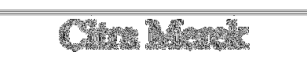 & WA1 \\
\hline
\end{tabular}

1) Variabel kualitas produk mempunyai nilai signifikan 0,734>0,05. Maka dapat disimpulkan bahwa secara individual variabel kualitas produk tidak berpengaruh secara signifikan terhadap variabel loyalitas nasabah.

2) Variabel kualitas layanan mempunyai nilai signifikan 0,001>0,05. Maka dapat disimpulkan bahwa secara individual variabel kualitas layanan berpengaruh secara signifikan terhadap variabel loyalitas nasabah.

3) Variabel citra merek mempunyai nilai signifikan 0,411>0,05. Maka dapat disimpulkan bahwa secara individual variabel citra merek tidak berpengaruh secara signifikan terhadap variabel loyalitas nasabah. 
c. Uji t model III

\section{Hasil Uji Signifikansi Parsial (Uji T)}

\begin{tabular}{|c|c|}
\hline \multirow{2}{*}{ Variabel } & Hasil Uji \\
\hline & SHa \\
\hline 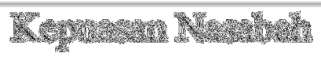 & 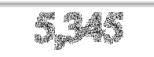 \\
\hline
\end{tabular}

Variabel kepuasan konsumen mempunyai nilai $\mathrm{t}$ hitung sebesar 12,417 dan taraf signifikan $0,000<$ 0,05. Maka dapat disimpulkan bahwa secara individual variabel kepuasan konsumen berpengaruh secara signifikan terhadap variabel loyalitas nasabah.

5. Hasil Uji Simultan (Uji F)

\begin{tabular}{|c|c|}
\hline F & Sig. \\
\hline 10,716 & 0,000 \\
\hline \multicolumn{2}{|c|}{ Sumber : Data Primer, 2017}
\end{tabular}

Dari hasil uji regresi linier berganda diperoleh $\mathrm{f}$ hitung kepuasan konsumen sebesar 10,716 dengan probabilitas $0,000<0,05$. Jika dibandingkan dengan alpha 0,05 , maka $0,000<0,05$ yang artinya variabel kualitas produk, kualitas layanan dan citra merek secara bersama - sama berpengaruh signifikan terhadap variabel kepuasan nasabah. Sehingga dapat disimpulkan bahwa Ha diterima dan Ho ditolak.

\begin{tabular}{|l|l|}
\hline F & Sig. \\
\hline 28,573 & 0,000 \\
\hline
\end{tabular}

Sumber : Data Primer, 2017

Begitu juga $f$ hitung loyalitas nasabah diperoleh $f$ hitung sebesar 28,573 dengan probabilitas $0,000>0,05$. Mempengaruhi signifikan antara variabel independen kepuasan nasabah terhadap variabel dependen loyalitas nasabah.

6. Hasil Uji Koefisien Determinasi

\begin{tabular}{|c|c|}
\hline Model & R Square \\
\hline 1 & 0,365 \\
\hline \multicolumn{2}{|c|}{ Sumber : Data Primer, 2017} \\
\hline
\end{tabular}

Berdasaran analisis yang dilakukan,model $\mathrm{I}$ nilai $\mathrm{R}$ Square, diketahui nilai koefisien determinasi ( $R$ Square) sebesar 0,365. Besarnya angka koefisien determinasi (R Square) 0,365 sama dengan $36,5 \%$. Angka tersebut mengandung arti bahwa variabel independen ( $\mathrm{X}_{1}$; Kualitas Produk, $\mathrm{X}_{2}$ : Kualitas Layanan, $\mathrm{X}_{3}$ : Citra Merek) berpengaruh terhadap variabel dependen ( $\mathrm{Z}$ : Kepuasan Nasabah) sebesar 36,5\%. Sedangkan sisanya $(100 \%-36,5 \%=63,5 \%)$ dipengaruhi oleh variabel lain diluar model regresi ini

\begin{tabular}{|c|c|}
\hline Model & R Square \\
\hline II & 0,266 \\
\hline \multicolumn{2}{|c|}{ Sumber : Data Primer, 2017}
\end{tabular}

Dari output hasil analisis model II uji R Square, diketahui nilai koefisien determinasi (R Square) sebesar 0,266. Besarnya angka koefisien determinasi (R Square) 0,266 sama dengan 26,6\%. Angka tersebut mengandung arti bahwa variabel independen (X1; Kualitas Produk, X2: Kualitas Layanan, X3: Citra Merek) berpengaruh terhadap variabel dependen (Y: Loyalitas Nasabah) sebesar 26,6\%. Sedangkan sisanya $(100 \%-26 \%=73,4 \%)$ dipengaruhi oleh variabel lain diluar model regresi ini.

\section{Pembahasan}

1. Pengaruh kualitas produk terhadap kepuasan nasabah

Dari uji hipotesis yang dilakukan bahwa kualitas produk mempunyai pengaruh yang positif terhadap kepuasan nasabah. Dalam menggunakan jasa perbankan Bank BRI Yogyakarta. Hal ini menunjukkan bahwa kualitas produk menentukan tingkat kepuasan nasabah terhadap jasa perbankan Bank BRI Yogyakarta. Hal ini menunjukkan bahwa hasil yang diterima nasabah pasca menggunakan layanan yang dilakukan oleh Bank BRI Yogyakarta berpengaruh terhadap kepuasan nasabah. 
Pada saat terjadi adanya kegagalan produk jasa maka konsumen berharap adanya kompensasi setelah terjadi kegagalan jasa. Kompensasi yang diterima pelanggan membuat pelanggan merasa senang sehingga akan timbul adanya kepuasan nasabah itu sendiri.

2. Pengaruh kualitas layanan terhadap kepuasan nasabah

Dari uji hipotesis yang dilakukan bahwa kualitas layanan mempunyai pengaruh yang positif terhadap kepuasan nasabah pada jasa perbankan Bank BRI Yogyakarta. Hal ini menunjukkan bahwa kualitas layanan menentukan tingkat kepuasan nasabah terhadap jasa perbankan Bank BRI Yogyakarta.

Dengan memberikan interaksi kepada nasabah, maka diharapkan nasabah akan merasa dihargai, diperhatikan dan dapat memahami situasi yang terjadi sehingga nasabah cenderung mengalami kepuasan yang lebih besar pada saat menggunakan layanan yang dilakukan oleh Bank BRI Yogyakarta Hal ini menunjukkan bahwa hasil yang diterima nasabah pasca menggunakan layanan yang dilakukan oleh Bank BRI Yogyakarta berpengaruh terhadap kepuasan nasabah.

3. Pengaruh citra merek terhadap kepuasan nasabah

Dari hasil analisis diketahui bahwa citra merek tidak berpengaruh positif pada kepuasan nasabah dalam menggunakan jasa perbankan Bank BRI Yogyakarta. Hal ini menunjukkan bahwa citra merek tidak menentukan tingkat kepuasan nasabah terhadap jasa perbankan Bank BRI Yogyakarta.

4. Pengaruh kualitas produk, kualitas layanan dan citra merek terhadap kepuasan nasabah

Dari hasil analisis diketahui bahwa kualitas produk, kualitas layanan dan citra merek secara bersama-sama berpengaruh positif pada kepuasan nasabah dalam menggunakan jasa perbankan Bank BRI
Yogyakarta. Hal ini menunjukkan bahwa kualitas produk, kualitas layanan dan citra merek menentukan tingkat kepuasan nasabah terhadap jasa perbankan Bank BRI Yogyakarta.

5. Pengaruh kualitas produk terhadap loyalitas nasabah

Dari uji hipotesis yang dilakukan bahwa kualitas produk tidak berpengaruh positif terhadap loyalitas nasabah. Dalam menggunakan jasa perbankan Bank BRI Yogyakarta. Hal ini menunjukkan bahwa kualitas produk tidak menentukan tingkat loyalitas nasabah terhadap jasa perbankan Bank BRI Yogyakarta. Pada saat terjadi adanya kegagalan produk jasa maka konsumen tidak terlalu berharap adanya kompensasi setelah terjadi kegagalan produk.

6. Pengaruh kualitas layanan terhadap loyalitas nasabah

Dari uji hipotesis yang dilakukan bahwa kualitas layanan mempunyai pengaruh yang positif terhadap loyalitas nasabah pada jasa perbankan Bank BRI Yogyakarta. Hal ini menunjukkan bahwa kualitas layanan menentukan tingkat loyalitas nasabah terhadap jasa perbankan Bank BRI Yogyakarta. Dengan memberikan interaksi kepada nasabah, maka diharapkan nasabah akan merasa dihargai, diperhatikan dan dapat memahami situasi yang terjadi sehingga nasabah cenderung mengalami kepuasan yang lebih besar pada saat menggunakan layanan yang dilakukan oleh Bank BRI Yogyakarta dan selanjutnya nasabah akan loyal terhadap jasa perbankan tersebut. Hal ini menunjukkan bahwa hasil yang diterima nasabah pasca menggunakan layanan yang dilakukan oleh Bank BRI Yogyakarta berpengaruh terhadap loyalitas nasabah.

7. Pengaruh citra merek terhadap loyalitas nasabah

Dari hasil analisis diketahui bahwa citra merek tidak berpengaruh positif pada 
loyalitas nasabah dalam menggunakan jasa perbankan Bank BRI Yogyakarta. Hal ini menunjukkan bahwa kualitas produk tidak menentukan tingkat loyalitas nasabah terhadap jasa perbankan Bank BRI Yogyakarta. Hal ini menunjukkan bahwa hasil yang diterima nasabah pasca menggunakan layanan yang dilakukan oleh Bank BRI Yogyakarta tidak berpengaruh terhadap loyalitas nasabah.

8. Pengaruh kualitas produk, kualitas layanan dan citra merek terhadap loyalitas nasabah

Dari hasil analisis diketahui bahwa kualitas produk, kualitas layanan dan citra merek secara bersama-sama berpengaruh positif pada loyalitas nasabah dalam menggunakan jasa perbankan Bank BRI Yogyakarta. Hal ini menunjukkan bahwa kualitas produk, kualitas layanan dan citra merek menentukan tingkat loyalitas nasabah terhadap jasa perbankan Bank BRI Yogyakarta.

9. Pengaruh kepuasan nasabah terhadap loyalitas nasabah

Dari hasil analisis diketahui bahwa kepuasan nasabah berpengaruh positif pada loyalitas nasabah. Dengan adanya nasabah Bank BRI yang puas terhadap pelayanan yang diberikan perusahaan memiliki cenderung untuk menggunakan jasa yang sama kedua kalinya dan menunjukkan loyalitas terhadap perbankan Bank BRI Yogyakarta. Sedangkan nasabah Bank BRI yang tidak puas terhadap pelayanan yang diberikan akan memilih perbankan yang lain atau masih tetap memilih untuk menggunakan perbankan Bank BRI Yogyakarta karena cabang dan unit dari perusahaan yang tersebar luas.

KESIMPULAN DAN SARAN

\section{Kesimpulan}

1. Kualitas produk berpengaruh positif terhadap kepuasan nasabah.

2. Kualitas layanan berpengaruh positif terhadap kepuasan nasabah.
3. Citra merek tidak berpengaruh positif terhadap kepuasan nasabah.

4. Kualitas Produk, kualitas layanan dan citra merek secara bersama-sama berpengaruh positif terhadap kepuasan nasabah.

5. Kualitas produk tidak berpengaruh positif terhadap loyalitas nasabah.

6. Kualitas layanan berpengaruh positif terhadap loyalitas nasabah.

7. Citra merek tidak berpengaruh positif terhadap loyalitas nasabah.

8. Kualitas Produk, kualitas layanan dan berpengaruh positif terhadap loyalitas nasabah.

9. Kepuasan nasabah berpengaruh positif terhadap loyalitas nasabah.

\section{Saran}

1. Dengan banyaknya jumlah responden yang menjawab setuju terhadap seluruh variabel penelitian (kualitas produk, kualitas layanan, citra merek, kepuasan nasabah dan loyalitas nasabah). Dengan adanya hal tersebut diharapkan Bank Rakyat Indonesia dapat lebih mempertahankan pelayanan yang memuaskan secara konsisten.

2. Nilai $R$ Square $\left(R_{2}\right)$ pada model $I$ diketahui sebesar 0,365. Besarnya angka koefisien determinasi (R Square) 0,365 sama dengan 36,5\%. Angka tersebut mengandung arti bahwa variabel independen mampu memberikan pengaruh terhadap variabel dependen sebesar 36,5\%. Sedangkan sisanya $(100 \%-36,5 \%=$ $63,5 \%$ ) dipengaruhi oleh variabel lain diluar model regresi ini.

3. Nilai $\mathrm{R}$ Square $\left(\mathrm{R}_{2}\right)$ pada model II sebesar sebesar 0,266. Besarnya angka koefisien determinasi (R Square) 0,266 sama dengan 26,6\%. Angka tersebut mengandung arti bahwa variabel independen mampu memberikan pengaruh terhadap variabel dependen sebesar 26,6\%. Sedangkan sisanya $(100 \%-26 \%=73,4 \%)$ dipengaruhi oleh variabel lain diluar model regresi ini. 


\section{DAFTAR PUSTAKA}

Aprilia, Diajeng Ayu. 2010. Analisis Pengaruh Kualitas Pelayanan terhadap Loyalitas Pelanggan dengan Kepuasan Pelanggan sebagai Mediasi. Universitas Sebelas Maret: Skripsi.

Fatrio, Novel. 2006. Analisis Faktor faktor yang Mempengaruhi Kepuasan Nasabah dalam Meningkatkan Loyalitas Nasabah (Studi Kasus: Pada PT. Bank Bukopin Kantor Cabang Tegal). Griffin, Jill. Customer Loyalty. Jakarta: $\quad 2005$.

Http://ib.bri.co.id

Http://smileboys.blogspot.co.id/2008 /07/pengertian-kualitas-produk.html.

Irawati dan Hery Syahrial. 2015. Pengaruh Kualitas Produk dan Kualitas Pelayanan terhadap Kepuasan Pelanggan Pengguna Modem Smartfren pada Mahasiswa Fakultas Ekonomi Universitas Medan Area. Medan: Jurnal Konsep Bisnis dan Manajemen. Vol. 1 No. 2 Mei 2015.

Karatepe, Osman M. 2011. Service Quality, Customer Satisfaction and Loyalty : The Moderating Role of Gender. Journal of Business Economics and Management Vol. 12(2): 278-300.

Kusuma, Rizal Wahyu. 2015. Pengaruh Kualitas Produk, Harga, Fasilitas dan Emosional Terhadap Kepuasan Pelanggan. Surabaya: Jurnal Ilmu dan Riset Manajemen. Vol. 4 No. 12 Desember 2015.

Kotler, Philip dan Gary Armstrong. Prinsip-prinsip Pemasaran. Jakarta: Erlangga. 2012.
Kotler, Philip dan Kevin Lane Keller. Manajemen Pemasaran. Jakarta: Erlangga. 2009.

Kotler, Philip dan Kevin Lane Keller. Manajemen Pemasaran. Jakarta: Erlangga. 2012.

Marwanto, Aris. Marketing Sukses. Yogyakarta: KOBIS. 2015. Novi, Amanita. Bank dan Lembaga Keuangan Lainnya. Yogyakarta: UNY. 2006.

Peter, J. Paul dan Jerry C. Olson. Perilaku Konsumen dan Strategi Pemasaran. Jakarta: Salemba Empat: 2014.

Puspitasari, Mei Gawati dan Mochamad Edris. 2011. Pengaruh Kualitas Layanan Terhadap Loyalitas dengan Mediasi Kepuasan Pasien Rawat Inap pada Keluarga Sehat Hospital Pati. Universitas Muria Kudus: Jurnal Analisis Manajemen Vol. 5 No. 2 Desember 2011.

Sangadji dan Sopiah. Perilaku Konsumen. Yogyakarta : Andi Yogyakarta. 2013.

Setyawan, Muhammad Arif. 2015. Pengaruh Kualitas Layanan dan Kualitas Produk Internet Banking terhadap Kepuasan Nasabah pada Bank BRI Pandaran Semarang. Universitas Negeri Semarang: Skripsi.

Sondakh, Conny. 2014. Kualitas Layanan, Citra Merek Dan Pengaruhnya Terhadap Kepuasan Nasabah Dan Loyalitas Nasabah Tabungan (Studi Pada Nasabah Taplus BNI Cabang Manado). Manado: Jurnal Riset Bisnis dan Manajemen Vol. 3 ,No.1, 2014:19-32.

Sugiyono. Metode Penelitian Manajemen. Bandung : Alfabeta. 2013. 
Suhardi, Gunarto. Usaha Perbankan dalam Perspektif Hukum. Yogyakarta:Kanisius. 2003.

Tjiptono, Fandy dan Gregorius Chandra. Pemasaran Strategik. Yogyakarta: ANDI. 2012.

Tjiptono, Fandy dan Gregorius Chandra. Service Quality dan Satisfaction. Yogyakarta: ANDI. 2016.

Tjiptono, Fandy. Strategi Pemasaran. Yogyakarta: ANDI. 2015 